\title{
Effect of low-pressure storage on the quality of green capsicums (Capsicum annum $L$.)
}

Penta Pristijono, Michael C. Bowyer, Christopher J. Scarlett, Quan V. Vuong, Costas E. Stathopoulos and John B. Golding

This is an Accepted Manuscript of an article published by

Taylor \& Francis in Journal of Horticultural Science and Biotechnology on 7th December 2017, available online: https://doi.org/10.1080/14620316.2017.1411768 
1 Effect of low pressure storage on the quality of green capsicums (Capsicum annum

$2 \quad L$.

3

4 Penta Pristijono $^{1 *}$, Michael C. Bowyer ${ }^{1}$, Christopher J. Scarlett $^{1}$, Quan V. Vuong ${ }^{1}$,

5 Costas E. Stathopoulos ${ }^{2}$, and John B. Golding ${ }^{1,3}$

$6{ }^{1)}$ School of Environmental and Life Sciences, University of Newcastle, Ourimbah,

$7 \quad$ NSW 2258, Australia

$8{ }^{2)}$ School of Science, Engineering and Technology, University of Abertay, Dundee DD1

$9 \quad 1 \mathrm{HG}, \mathrm{UK}$

10 3) NSW Department of Primary Industries, Locked Bag 26 Gosford, NSW 2250,

11 Australia

12

13 *Corresponding author: Dr Penta Pristijono; email: penta.pristijono@newcastle.edu.au;

14 School of Environmental and Life Sciences, University of Newcastle, PO Box 127,

15 Ourimbah - NSW 2258, Australia.

16

17 


\section{Abstract}

Green capsicums (Capsicum annum L.) were stored under low pressure (4 kPa) at $10^{\circ} \mathrm{C}$ for 5 and 11 days with $100 \% \mathrm{RH}$. The results showed that the incidence of stem decay under low pressure storage for 5 and 11 days and storage at ambient atmosphere

22 at $20^{\circ} \mathrm{C}$ for three days lower compared to fruits that were stored at regular atmosphere at $2310^{\circ} \mathrm{C}$. Fruit that had been stored at low pressure at $10^{\circ} \mathrm{C}$ had no symptoms of flesh rots 24 for up to 11 days, whilst fruit which had been stored at regular atmosphere at $10^{\circ} \mathrm{C}$ had $256 \%$ flesh rots after 11 days storage at $10^{\circ} \mathrm{C}$. There was no difference in flesh firmness 26 and colour retention between fruits stored at low pressure and regular pressure at $10^{\circ} \mathrm{C}$.

27 Capsicums stored at low pressure had higher overall acceptability compared to fruit that 28 were stored at regular atmosphere at $10^{\circ} \mathrm{C}$. These results demonstrate the potential of 29 low pressure storage as an effective technique to manage capsicum fruit quality, 30 however there was no additional benefit when fruits were stored at low pressure for 31 more than 5 days.

32 Keywords: Capsicum annum L.; low pressure; colour; firmness; flesh rots; stem decay 


\section{Introduction}

Green capsicums or bell peppers (Capsicum annum L.) are harvested at fully mature green stage for fresh consumption. Green capsicum fruit are highly perishable and rapidly lose quality after harvest. The major limiting factors for the storage of green capsicums includes skin colour degreening, flesh shrivel and rots affecting both the

39 flesh and calyx/stem. Shrivel is a result of moisture loss from the fruit and is a

40 consequence of storage in low humidity and is exacerbated by the hollow centre of capsicum fruit (O’Donoghue et al., 2013). The calyx (stem) of capsicum fruit can also be affected by moisture loss where localized 'die-back' of the tissues can occur (O’Donoghue, et al., 2013). Another storage problem of capsicums is postharvest degreening of the green capsicums. This significantly downgrades consumer acceptance, as the retention of the green skin colour is a key determinant of consumer preference.

The recommended storage conditions for capsicums is $8^{\circ} \mathrm{C}$ with $95 \%$ relative humidity (RH) (Cantwell \& Kasmire, 2011). Capsicums are susceptible to chilling damage at lower storage temperatures $\left(<7^{\circ} \mathrm{C}\right)$, although this is cultivar and ripeness dependent. However storage at higher storage temperatures, particularly at elevated humidity often results in the growth of postharvest pathogens (Lim et al., 2007). Both chilling injury and rot development are not often visible during storage, but develop after the fruit warms to room temperature (Balandrán-Quintana et al., 2003) and are responsible for important economic losses.

A range of pre-storage treatments prior to cold storage have been developed to maintain green capsicum quality. Current potential treatment methods to maintain the

57 quality of green capsicums include coatings with chitosan (Xing et al., 2011),

58 Semperfresh ${ }^{\mathrm{TM}}$ (composed of sucrose esters of fatty acids, sodium carboxymethyl 
cellulose and mon-odiglycerides of fatty acids) (Özden \& Bayindirli, 2002), and treatment with 1-methylcyclopropene (Fernández-Trujillo et al., 2009). Hot water treatment $\left(50-53^{\circ} \mathrm{C}\right)$ was also reported as a method to improve the quality of capsicums (Fallik et al.1996; González-Aguilar et al., 2000), while (Elazar Fallik et al., 1999) further showed that capsicums brushed with hot water $\left(55^{\circ} \mathrm{C}\right)$, prevented fruit decay during transport.

Low pressure storage technology has been around for many years but it has recently re- emerged as a technique which can rapidly remove the heat, reduce the oxygen level and rapidly remove and manage the storage atmosphere (Wang et al., 2001). Unlike other physical treatments (such as heat, gamma irradiation and ultra violet, a potential advantage of pressure treatment is the homogeneity of application during treatment (Vigneault et al., 2012). Most modern low pressure systems utilise a method to maintain high humidity to lower water loss and wilting, where the low pressure treatment also lowers respiration, and ethylene production to delay fruit ripening during storage (Burg, 2004). Low pressure storage can also incorporate reliable adjustment of the storage temperature and atmospheric composition, which can effectively overcome disadvantages associated with atmospheric refrigeration and controlled atmosphere storage processes (Li et al., 2006).

Low pressure storage based on sub-atmospheric pressure has been shown to extend the storage and shelf-life of many horticultural crops such as bananas (Burg \& Burg , 1966), mango (Apelbaum et al., 1977), strawberries (An et al., 2009), Chinese bayberry (Chen et al., 2013) and tomato (Pristijono et al., 2017b). There are limited studies of the effect of low pressure storage on the quality of green capsicums. (Burg, 2004) reported that peppers tolerated two days exposure to a pressure of $2.67 \mathrm{kPa}$ at 12 $13^{\circ} \mathrm{C}$, however longer exposure times have not been examined. This study examined the 
84 effectiveness of low pressure storage $(4 \mathrm{kPa})$ at $10^{\circ} \mathrm{C}$ for 5 and 11 days with the addition of a three days shelf-life at regular pressure $(101 \mathrm{kPa})$ at $20^{\circ} \mathrm{C}$, to maintain the quality of green capsicums.

\section{Materials and methods}

Fruits

Local fresh green capsicum fruit (Capsicum annum L.), free from damage and uniform in size were obtained from the local wholesale market. Non-blemished fruit (260 - 270 g) were randomly selected, weighed and sorted into experimental units. The experimental design was completely randomized, consisting three treatment units (a) regular pressure of $101 \mathrm{kPa}$ at $20^{\circ} \mathrm{C}$, (b) regular pressure of $101 \mathrm{kPa}$ at $10^{\circ} \mathrm{C}$ and (c) low pressure of $4 \mathrm{kPa}$ at $10^{\circ} \mathrm{C}$. Each experimental unit consisted of 16 fruits which was replicated three times for treatment and storage period (5 and 11 days).

\section{Low pressure storage system}

A laboratory scale low pressure system (VivaFresh ${ }^{\mathrm{TM}}$ ) with six identical low pressure aluminium chambers $\left(0.61 \mathrm{~L} \times 0.43 \mathrm{~W} \times 0.58 \mathrm{H} \mathrm{m}^{3}\right)$ was used in the study. Low pressure was achieved using a two-stage rotary vacuum pump (Model 2005I, Alcatel Adixen, USA) regulated by a compact proportional solenoid valve controlled by a proportional/integral/derivative (PID) computer control system. The system was equipped with an air flow controller to adjust the air exchange rate which was used to prevent build-up of metabolic gases given off by the fruit. A humidifier was used to ensure the inflowing rarefied air was humidified before entering the low pressure chamber. Relative humidity in the system was calculated by measuring wet-bulb and 
109 dry-bulb temperatures using calibrated YSI 55000 Series GEM thermistors. Sensors

110 inside the low pressure chambers were used to record the temperature, humidity and

111 pressure during treatment. All data from temperature and pressure sensors in the LP

112 system were digitised and sent to a computer control box and recording system via

113 Ethernet cable port. The six different chambers were located inside two cool rooms at

$11410^{\circ} \mathrm{C}$, where three chambers were allocated to 5 days storage and three chambers for 11

115 days.

116

117 Experimental procedures of storage

118 Each treatment unit of 16 fruits was placed into an unsealed plastic container (45

$119 \mathrm{~cm} \times 20 \mathrm{~cm} \times 15 \mathrm{~cm}$ ) and placed into the low pressure chamber, where the pressure,

120 temperature and humidity were maintained at $4 \mathrm{kPa}, 10^{\circ} \mathrm{C}$ and $100 \%$, respectively.

121 Each replicate used an independent separate low pressure chamber (total of 6 low

122 pressure chambers). Two sets of control fruit which each consisted 16 fruits were placed

123 onto a plastic tray at either $101 \mathrm{kPa} 10^{\circ} \mathrm{C}$ or $20^{\circ} \mathrm{C}$, and covered with a loose low density

124 polyethylene (LDPE) plastic bag $(66 \mathrm{~cm} \times 58 \mathrm{~cm})$ to maintain the RH of $97 \%$ around

125 the produce during storage. Fruits were assessed immediately upon removal (after the

126 fruit had warmed to room temperature) after 5 and 11 days from $10^{\circ} \mathrm{C}$ and after

127 additional three days storage at $101 \mathrm{kPa} 20^{\circ} \mathrm{C}$. Calibrated loggers (TinyTag View 2)

128 were used to monitor temperature and relative humidity within each treatment.

$130 \quad$ Fruit quality assessment

131 Fruit quality assessment included; weight loss, stem rots, colour, flesh rots, fruit

132 firmness and overall acceptability. The weight loss was calculated as percentage based

133 on the initial weight of capsicums and weight after storage. 
Skin colour changing was assessed visual based on a grading scale from 1 to 4 , where $1=$ severe degreening mainly orange or red; $2=50-75 \%$ green; $3=$ more than $75 \%$ green; and $4=100 \%$ green (Figure 1). The skin colour changing index was expressed as : colour changing index $(\%)=\sum[$ (degreening level $) \times($ number of fruit at this level) $] /($ highest level $\times$ total number of fruit in the treatment $) \times 100$.

The incidence of flesh rots were visually assessed and scored based on the

140 percentage of total flesh area containing the number of black rots, using the following

141 scores; $1=$ severe rots or $>50 \%$ affected; $2=$ moderate rots, two spots or large lesion;

$1423=$ slight rots or noticeable black rots of one to two spots; and $4=$ fresh with no

143 symptoms of rots. The flesh rots rate was calculated according to Wang et al. (2015)

144 with some slight modifications. The calculation as calyx rots index $(\%)=\sum[($ rot

145 score $) \times($ number of fruit at this level $)] /($ highest level $\times$ total number of fruit in the 146 treatment) $\times 100$.

147 Stem decay was subjectively evaluated using an subjective grading scale from 1 148 to 4 , where $1=$ severe decay or $>50 \%$ rotten; $2=$ moderate decay, soft, water soaked 149 lesions, noticeable or $25-50 \%$ stem rotten; $3=$ slight, small spots, affecting $<25 \%$

150 stem decay; and $4=$ no symptoms of stem decay. The stem decay was calculated 151 according to Pristijono et al. (2017b) with some slight modifications. The stem decay 152 index was expressed as: stem decay index $(\%)=\sum[$ (decay level $) \times($ number of fruit at 153 this level) $] /($ highest level $\times$ total number of fruit in the treatment $) \times 100$.

154 Green capsicums firmness was measured according to Pristijono et al. (2017a), 155 with some slight modifications, where the firmness determined as the maximum force 156 (Lloyd Texture Analyser, Fareman, UK), required to push a $68 \mathrm{~mm}^{2}$ flat probe into the 157 fruit flesh to a depth of $7 \mathrm{~mm}$. The average of two reading points from each side of the 158 fruit was taken three $\mathrm{cm}$ from calyx-end. The firmness results were expressed in 
159 Newton (N). The overall acceptability index was estimated based on the fruit freshness

160 combination of the level of skin discoloration, stem and flesh rotted, scoring from 1 to

1614 , where, score $1=$ poor, consumer would throw away; 2 = not saleable but edible,

162 acceptable for cooking; $3=$ less than $20 \%$ skin degreening and with slight stem and

163 flesh rots; and $4=$ fresh with no symptom of stem and flesh rots and discolouration. The

164 fruits overall acceptability index was assessed according to Pristijono et al. (2017a),

165 with some slight modifications. The acceptability index was expressed as: acceptability

166 index $(\%)=\sum[($ acceptable level $) \times($ number of fruit at this level $)] /($ highest level $\times$ total

167 number of fruit in the treatment) $\times 100$.

168

169 Statistical analysis

170 Statistical analysis was performed using Statistical Analysis System - version

1719.4 (SAS Institute, Cary, NC, USA) and SPSS (ver 23, IBM, USA). All data were

172 analysed for homogeneity of variance and then subjected to one-way analysis of

173 variance (ANOVA). The mean values were evaluated by using least significant

174 differences (LSD) test with $p<0.05$ as the level of statistical significance.

175

176 Results and discussions

177

178 Weight loss

179 Weight loss is an important indicator of capsicum quality deterioration, as

180 weight loss can lead to wilting and shrivelling which reduces both market value and

181 consumer acceptability. Shrivel is due to moisture loss, and is a consequence of low

182 storage humidity and is further exacerbated by the hollow nature of capsicum fruit

183 (O'Donoghue, et al., 2013). Results in Table 1 show that after 11 days storage, 
184 capsicums stored in regular atmosphere pressure $(101 \mathrm{kPa})$ at $20^{\circ} \mathrm{C}$ had significantly

185 greater weight loss than fruits stored at $10^{\circ} \mathrm{C}$ under either low pressure $(4 \mathrm{kPa})$ or

186 regular pressure $(101 \mathrm{kPa})$. The results are in accordance with previous research

187 conducted on tomato which found weight loss to vary in proportion to storage

188 temperature (De Castro et al., 2006).

189 In this study, low pressure storage did not significantly affect weight loss of 190 capsicums stored at regular atmosphere at $10^{\circ} \mathrm{C}$ for 5 or 11 days. These findings are in 191 agreement with previous findings by Hashmi et al. (2013) who reported that low

192 pressure treatment did not affect the weight loss of strawberries. However these

193 observations contradict findings reported by Hughes et al.,(1981) who found that

194 weight loss in 'Bellboy' peppers stored in low pressures $(5.1,10.1$ and $20.3 \mathrm{kPa})$ at

$1958.8^{\circ} \mathrm{C}$ (storage time not specified) was at least five times greater than control fruit stored

196 under regular pressure conditions but the RH of this experiment were not reported.

197 Laurin et al. (2006) who also reported that low pressure treatment (71 kPa, 6 hours,

$19820^{\circ} \mathrm{C}$ ) increased weight loss of Alpha-type cucumbers. Further, (Burg, 2004) also

199 reported that 'Acorn' squash stored at $7.33-8 \mathrm{kPa}$ at $7^{\circ} \mathrm{C}$ and $90-95 \% \mathrm{RH}$ for 11 days

200 experienced a weight loss of $4.2 \%$.

201 As expected in terms of storage time, fruit stored for 5 days resulted in

202 significantly lower in weight loss than 11 days storage for fruits stored either at regular

203 pressure at $20^{\circ} \mathrm{C}$ or low pressure and regular pressure at $10^{\circ} \mathrm{C}$. The results show that

204 fruit stored at $20^{\circ} \mathrm{C}$ resulted in significantly higher weight loss than that stored at with

205 low pressure or regular pressure atmosphere at $10^{\circ} \mathrm{C}$ and that the longer storage time

206 increased weight loss regardless the pressures treatment during storage. 
210 their quality is often determined based on appearance including skin colour. In this

211 study, initial skin colour of green capsicums was uniformly dark green with a Hue angle

212 of 121.0 (high hue value corresponds to dark green). However during storage, the skin

213 colour turned partly yellow. This colour change was difficult to objectively assess using

214 a colorimeter because of the non-uniformity of colour change, therefore skin colour

215 change was assessed based on the grading scale (Figure 1).

216 The fruit's skin colour was assessed both immediately after capsicums were

217 removed from low pressure treatment of $4 \mathrm{kPa}$ at $10^{\circ} \mathrm{C}$ for 5 or 11 days, and after the

218 fruit were transferred to $20^{\circ} \mathrm{C}$ at regular atmosphere $(101 \mathrm{kPa})$ for 3 days. There was a

219 significant difference between regular pressure at $20^{\circ} \mathrm{C}$ and low pressure storage $(4 \mathrm{kPa})$

220 at $10^{\circ} \mathrm{C}$ after capsicums were stored for 5 and 11 days (Table 1). As expected the skin

221 colour changes were greater when the fruit were stored subsequently for the additional 3

222 days at regular pressure $20^{\circ} \mathrm{C}$. However there was no significant difference in colour

223 changes observed between fruit stored at low pressure $(4 \mathrm{kPa})$ and regular atmosphere

224 pressure $(101 \mathrm{kPa})$ at $10^{\circ} \mathrm{C}$ for both storage times of 5 and 11 days upon removal and

225 after being transferred 3 days at regular pressure at $20^{\circ} \mathrm{C}$. This observation is similar

226 with previous study by Burg (2004) who reported that 'Neusiedler Ideal' peppers

227 remained green after treatment at $10 \mathrm{kPa}$ for 23 days at $10-12^{\circ} \mathrm{C}$ and 'Acorn' squash

228 peel also remained green after fruit storage at low pressure of $7.33-8 \mathrm{kPa}$ for 11 days

229 at $7^{\circ} \mathrm{C}$.

230

$231 \quad$ Firmness

232 In this study, fruit firmness was assessed both immediately after capsicums

233 were stored under low pressure of $4 \mathrm{kPa}$ at $10^{\circ} \mathrm{C}$ for 5 or 11 days, and transferred to 
$23420^{\circ} \mathrm{C}$ under regular pressure $(101 \mathrm{kPa})$ for 3 days. The results of the objective

235 measurement of fruit firmness are presented in Table 1 and show the maintenance of

236 firmness in fruit stored at $10^{\circ} \mathrm{C}(4$ and $101 \mathrm{kPa})$ compare to those stored at regular

237 pressure at $20^{\circ} \mathrm{C}$. However there was no significant difference in fruit firmness between

238 fruit stored at low pressure storage $(4 \mathrm{kPa}) 10^{\circ} \mathrm{C}$ and regular pressure $(101 \mathrm{kPa})$ at $10^{\circ} \mathrm{C}$

239 storage temperature for both storage time of 5 and 11 days upon removal and after being

240 stored 3 days at regular pressure at $20^{\circ} \mathrm{C}$. These observations are consistent with those

241 previously reported by (Burg, 2004) who found that 'Neusiedler Ideal' peppers

242 remained firm after storage at $10-12^{\circ} \mathrm{C}$ under $10 \mathrm{kPa}$ for 23 days. Similarly, Hashmi et

243 al. (2016) found that low pressure treatment $(50 \mathrm{kPa})$ of strawberries had no beneficial

244 effect on fruit firmness, whilst Pristijono et al., (2017b) reported that tomatoes firmness

245 did not change with low pressure treatment $\left(4 \mathrm{kPa}, 10^{\circ} \mathrm{C}, 11\right.$ days $)$.

246 Comparing the storage time, there was no significant difference in fruit firmness

247 between capsicums stored at low pressure at $10^{\circ} \mathrm{C}$ for 5 and 11 days. This also relates

248 to the water loss data, where there was no difference between the different treatment

249 times, however future study needs to consider a longer time of storage for capsicums if

250 the firmness is considered as a major quality parameter.

Flesh rots

There was no effect on flesh rots following treatment with at low pressure $10^{\circ} \mathrm{C}$

254 for 5 days upon removal, however when green capsicums treated with low pressure

255 storage $(4 \mathrm{kPa})$ at $10^{\circ} \mathrm{C}$ for 11 days flesh rots were significantly lower levels in

256 comparison with the control fruit stored at regular atmosphere at both $10^{\circ} \mathrm{C}$ and $20^{\circ} \mathrm{C}$

257 and subsequently held at regular atmosphere at $20^{\circ} \mathrm{C}$ for 3 days (Figure 2). The results

258 are agreement with previous report by (J. Wang et al., 2015) which found that 'Honey' 
peaches stored at low pressure of 10-80 $\mathrm{kPa}$ resulted in significantly lower level of

260 fruits rots after 30 days storage at $0^{\circ} \mathrm{C}$. Romanazzi et al. (2001) also reported that

261 strawberries were stored at low pressure of $25 \mathrm{kPa}$ at $20^{\circ} \mathrm{C}$ for four hours significantly

262 reduced the percentage of fruits affected by grey mould as compared to control. The

263 difference in flesh rots between regular pressure and low pressure at $10^{\circ} \mathrm{C}$ may due to

264 low level of oxygen availability during the storage (less than $1 \% \mathrm{O}_{2}$ ) because pathogen

265 and spore germination has been shown to be inhibited when the level of oxygen is

266 between $0.1-0.25 \%$ (Burg, 2004). Therefore the development of rots after removal

267 from low pressure storage is slower than fruits stored continuously at atmospheric

268 pressure (Figure 2b).

269 Comparing the level of flesh rots between 5 and 11 days storage, the results

270 showed that after fruit was stored at low pressure $\left(4 \mathrm{kPa}, 10^{\circ} \mathrm{C}\right)$ for 5 days, there was no

271 differential effect between low pressure and atmospheric pressure treatments on flesh

272 rot. By contrast, fruits stored at low pressure $(4 \mathrm{kPa})$ and $10^{\circ} \mathrm{C}$ for 11 days showed

273 significantly lower incidence of flesh rots compared with fruit stored at $10^{\circ} \mathrm{C}$ at regular

274 pressure. This observation continued in the fruit that was removed from low pressure

275 and subsequently stored at regular pressure for 3 days at $20^{\circ} \mathrm{C}$. The results show that

276 low pressure treatment exerts a significant positive effect on reducing capsicum flesh

277 rots after 11 days storage.

278

279 Stem decay

280 Stem freshness is another important quality parameter for capsicum fruit. The

281 effect of low pressure storage on the incidence of stem decay in green capsicum is

282 presented in Figure 3. The results show that low pressure storage $\left(4 \mathrm{kPa}, 10^{\circ} \mathrm{C}\right)$ did not

283 significantly reduce the incidence of stem decay compared with fruit stored at regular 
284 pressure $\left(101 \mathrm{kPa}, 10^{\circ} \mathrm{C}\right)$ after 5 and 11 days storage upon removal. However fruit 285 stored at regular atmosphere at $20^{\circ} \mathrm{C}$ had significantly higher stem decay incidence 286 compared with fruit stored at $10^{\circ} \mathrm{C}(4$ or $101 \mathrm{kPa})$. Fruit treated with low pressure $\left(4 \mathrm{kPa}, 10^{\circ} \mathrm{C}\right)$ had $9 \%$ lower stem rots than fruit treated at regular pressure $\left(101 \mathrm{kPa}\right.$, at $\left.10^{\circ} \mathrm{C}\right)$ for 5 and 11 days and subsequently stored at regular pressure at $20^{\circ} \mathrm{C}$ for a further 3 days. The constant low rate of stem decay may be affected by the decay incidence when fruits were stored at low pressure due to low oxygen level, therefore when fruits were transferred to regular pressure at $20^{\circ} \mathrm{C}$, the decay rate of fruits were stored at low pressure and control fruits resume to the normal rate where the untreated fruits had already higher decay rate than fruits were

294 stored at low pressure. Burg (2004) reported that fungus growth resumed at the normal 295 rate after the fungus were transfered from low pressure to regular pressure atmosphere. The findings of the current studies are consistent with a previous report by Pristijono et al. (2017b) who demonstrated that tomatoes stored at low pressure $\left(4 \mathrm{kPa}, 10^{\circ} \mathrm{C}\right)$ for 11 days reduced the incidence of calyx rots. While the findings around low pressure treatment are promising, further mechanistic studies are required to fully understand the

300 mode of action associated with the reduction in stem decay.

Acceptability index

Overall acceptability of the fruit was visually assessed based on the combination

304 of flesh rot, stem decay and skin discolouration. The impact of low pressure storage on 305 overall visual acceptability of green capsicums is presented in Figure 3 and shows that 306 green capsicums which were stored at $10^{\circ} \mathrm{C}(4$ or $101 \mathrm{kPa})$ had higher overall

307 aceptability levels than fruits which were stored at regular pressure $(101 \mathrm{kPa})$

308 atmosphere $20^{\circ} \mathrm{C}$ after 5 and 11 days storage upon removal. The higher level of 
acceptability was found in fruit treated at low pressure $\left(4 \mathrm{kPa}, 10^{\circ} \mathrm{C}\right)$ and subsequently

310 stored at regular pressure $(101 \mathrm{kPa})$ at $20^{\circ} \mathrm{C}$ for 3 days, with the acceptability indices of

31181 and $76 \%$ for storage times of 5 and 11 days respectively. These results are consistent

312 with (Burg, 2004) who reported that peppers stored at low pressure of $12.7 \mathrm{kPa}$ at $7.2^{\circ} \mathrm{C}$

313 exhibited better fruit condition than fruit stored at regular pressure. In this study, overall

314 acceptability results were associated with reduced stem decay, lower levels of flesh rots

315 and skin degreening. These findings show that green capsicums stored at a pressure of 4

$316 \mathrm{kPa}$ combined and temperature of $10^{\circ} \mathrm{C}$ for at least 5 days improved fruit acceptability

317 by maintaining overall freshness and acceptability.

\section{Conclusions}

In conclusion, the low pressure treatment of $4 \mathrm{kPa}$ at $10^{\circ} \mathrm{C}$ for 5 or 11 days

maintained the quality of capsicums during storage. Low pressure storage reduced the incidence of flesh rots, stems decay and increased acceptability. Low pressure treatment also maintained the fruit firmness and colour retention and reduced weight loss relative to regular atmosphere storage. These were also maintained with a subsequent shelf life assessment for three days at $20^{\circ} \mathrm{C}$ in regular atmosphere $(101 \mathrm{kPa})$. However, except for the occurring flesh rots incidence, there was no further benefit to store green capsicums at low pressure more than 5 days at $10^{\circ} \mathrm{C}$.

\section{Acknowledgements} chambers.

\section{Funding}


336 Horticulture Innovation Australia and AusVeg (Project VG13043). The project was also supported by the University of Newcastle and the Australian Research Council Training Centre for Food and Beverage Supply Chain Optimisation (IC140100032).

\section{References}

341 An, D. S., Park, E., \& Lee, D. S. (2009). Effect of hypobaric packaging on respiration and quality of strawberry and curled lettuce. Postharvest Biology and Technology, 52(1), 78-83. doi: http://dx.doi.org/10.1016/j.postharvbio.2008.09.014 Apelbaum, A., Zauberman, G., \& Fuchs, Y. (1977). Subatmospheric pressure storage of mango fruits. Scientia Horticulturae, 7, 153-160. doi: doi:10.1016/03044238(77)90055-3

347 Balandrán-Quintana, R. R., Mendoza-Wilson, A. M., Gardea-Béjar, A. A., Vargas348 Arispuro, I., \& Angel Martínez-Téllez, M. (2003). Irreversibility of chilling injury in 349 zucchini squash (Cucurbita pepo L.) could be a programmed event long before the

350 visible symptoms are evident. Biochemical and Biophysical Research Communications, 351 307(3), 553-557. doi: http://dx.doi.org/10.1016/S0006-291X(03)01212-9

352 Burg, S. P. (2004). Postharvest physiology and hypobaric storage of fresh produce 353 (2004 ed.). Cambridge, MA, USA: CABI Publisher.

354 Burg, S. P., \& Burg. E.A. (1966). Fruit storage at subatmospheric pressure. Science, 355 153(3733), 314-315.

356 Cantwell, M. I., \& Kasmire, R. E. (2011). Postharvest Handling Systems : Fruits and 357 Vegetables. In A. A. Kader (Ed.), Postharvest Technology of Horticultural Crop (E358 edition of third ed., pp. 407-422). Oakland, California, USA: University of California, 359 Agriculture and Natural Resources Publication 3527. 
360 Chen, H., Yang, H., Gao, H., Long, J., Tao, F., Fang, X., et al. (2013). Effect of

361 hypobaric storage on quality, antioxidant enzyme and antioxidant capability of the

362 Chinese bayberry fruits. Chemistry Central Journal 7, 1-7.

363 De Castro, L., Cortez, L., \& Vigneault, C. (2006). Effect of sorting, refrigeration and

364 packaging on tomato shelf life. Journal of Food, Agriculture and Environment, 4, 70-

36574.

366 Fallik, E., Grinberg, S., Alkalai, S., \& Lurie, S. (1996). The effectiveness of postharvest

367 hot water dipping on the control of grey and black moulds in sweet red pepper

368 (Capsicum annuum). [Article]. Plant Pathology, 45(4), 644-649.

369 Fallik, E., Grinberg, S., Alkalai, S., Yekutieli, O., Wiseblum, A., Regev, R., et al.

370 (1999). A unique rapid hot water treatment to improve storage quality of sweet pepper.

371 Postharvest Biology and Technology, 15(1), 25-32. doi: http://doi.org/10.1016/S0925-

$372 \quad 5214(98) 00066-0$

373 Fernández-Trujillo, J. P., Serrano, J. M., \& Martínez, J. A. (2009). Quality of red sweet

374 pepper fruit treated with 1-MCP during a simulated post-harvest handling chain.

375 [Article]. Food Science and Technology International, 15(1), 23-30. doi:

$376 \quad 10.1177 / 1082013208100464$

377 González-Aguilar, G. A., Gayosso, L., Cruz, R., Fortiz, J., Báez, R., \& Wang, C. Y.

378 (2000). Polyamines induced by hot water treatments reduce chilling injury and decay in

379 pepper fruit. Postharvest Biology and Technology, 18(1), 19-26. doi:

380 http://doi.org/10.1016/S0925-5214(99)00054-X

381 Hashmi, M. S., East, A. R., Palmer, J. S., \& Heyes, J. A. (2013). Hypobaric treatment

382 stimulates defence-related enzymes in strawberry. Postharvest Biology and Technology,

383 85(0), 77-82. doi: http://dx.doi.org/10.1016/j.postharvbio.2013.05.002 
384 Hughes, P. A., Thompson, A. K., Plumbley, R. A., \& Seymour, G. B. (1981). Storage of 385 Capsicums (Capsicum Annuum (L.) Sendt.) Under Controlled Atmosphere, Modified 386 Atmosphere and Hypobaric Conditions. Journal of Horticultural Science, 56(3), 261387 265. doi: 10.1080/00221589.1981.11514999

388 Laurin, É., Nunes, M. C. N., Émond, J.-P., \& Brecht, J. K. (2006). Residual effect of 389 low-pressure stress during simulated air transport on Beit Alpha-type cucumbers:

390 Stomata behavior. Postharvest Biology and Technology, 41(2), 121-127. doi:

391 http://dx.doi.org/10.1016/j.postharvbio.2005.09.012

392 Li, W., Zhang, M., \& Yu, H.-q. (2006). Study on hypobaric storage of green asparagus. 393 Journal of Food Engineering, 73(3), 225-230. doi:

394 http://dx.doi.org/10.1016/j.jfoodeng.2005.01.024

395 Lim, C. S., Kang, S. M., Cho, J. L., Gross, K. C., \& Woolf, A. B. (2007). Bell Pepper 396 (Capsicum annuum L.) Fruits are Susceptible to Chilling Injury at the Breaker Stage of 397 Ripeness. HortScience, 42(7), 1659-1664.

398 O’Donoghue, E. M., Somerfield, S., McLachlan, A., Olsson, S., \& Woolf, A. (2013).

399 High-pressure water washing and continuous high humidity during storage and shelf 400 conditions prolongs quality of red capsicums (Capsicum annuum L.). Postharvest 401 Biology and Technology, 81, 73-80. doi:

402 http://doi.org/10.1016/j.postharvbio.2013.02.012

403 Özden, Ç., \& Bayindirli, L. (2002). Effects of combinational use of controlled 404 atmosphere, cold storage and edible coating applications on shelf life and quality 405 attributes of green peppers. [Article]. European Food Research and Technology, 406 214(4), 320-326. doi: 10.1007/s00217-001-0448-z

407 Pristijono, P., Papoutsis, K., Scarlett, C. J., Bowyer, M. C., Vuong, Q. V., Stathopoulos, 408 C. E., et al. (2017a). Postharvest UV-C treatment combined with 1-methylcyclopropene 
409 (1-MCP), followed by storage in continuous low-level ethylene atmosphere, improves

410 the quality of tomatoes. The Journal of Horticultural Science and Biotechnology, 1-9.

411 doi: $10.1080 / 14620316.2017 .1300512$

412 Pristijono, P., Scarlett, C. J., Bowyer, M. C., Vuong, Q. V., Stathopoulos, C. E., Jessup, 413 A. J., et al. (2017b). Use of Low Pressure Storage to Improve the Quality of Tomatoes.

414 The Journal of Horticultural Science and Biotechnology, 1-8. doi:

415 http://dx.doi.org/10.1080/14620316.2017.1301222

416 Romanazzi, G., Nigro, F., Ippolito, A., \& Salerno, M. (2001). Effect of short hypobaric

417 treatments on postharvest rots of sweet cherries, strawberries and table grapes.

418 Postharvest Biology and Technology, 22(1), 1-6. doi: http://dx.doi.org/10.1016/S0925-

$419 \quad 5214(00) 00188-5$

420 Vigneault, C., Leblanc, D. I., Goyette, B., \& Jenni, S. (2012). Invited review:

421 Engineering aspects of physical treatments to increase fruit and vegetable

422 phytochemical content. Canadian Journal of Plant Science, 92(3), 373-397. doi:

$423 \quad 10.4141 / C j p s 2011-222$

424 Wang, J., You, Y., Chen, W., Xu, Q., Wang, J., Liu, Y., et al. (2015). Optimal

425 hypobaric treatment delays ripening of honey peach fruit via increasing endogenous

426 energy status and enhancing antioxidant defence systems during storage. Postharvest

427 Biology and Technology, 101(0), 1-9. doi:

428 http://dx.doi.org/10.1016/j.postharvbio.2014.11.004

429 Wang, L., P.,, Zhang, P., \& Wang, S. J. (2001). Advances in research on theory and

430 technology for hypobaric storage of fruit and vegetable. Storage and Process 5, 3-6.

431 Xing, Y., Li, X., Xu, Q., Yun, J., Lu, Y., \& Tang, Y. (2011). Effects of chitosan coating

432 enriched with cinnamon oil on qualitative properties of sweet pepper (Capsicum 
433 annuum L.). [Article]. Food Chemistry, 124(4), 1443-1450. doi:

434 10.1016/j.foodchem.2010.07.105

435

436 
437 Table 1. The weight loss, firmness and colour changes of green capsicums after stored 438 at low pressure.

439

\begin{tabular}{|c|c|c|c|}
\hline Treatments & $\begin{array}{l}\text { Weight loss } \\
\qquad(\%)\end{array}$ & $\begin{array}{l}\text { Firmness } \\
\qquad(\mathrm{N})\end{array}$ & $\begin{array}{c}\text { Colour } \\
\text { Retention }(\%)\end{array}$ \\
\hline \multicolumn{4}{|l|}{ Upon removal } \\
\hline $101 \mathrm{kPa} 20^{\circ} \mathrm{C}, 5$ days & $0.5^{\mathrm{a}}$ & $21.4^{\mathrm{a}}$ & $79^{a}$ \\
\hline $101 \mathrm{kPa} 10^{\circ} \mathrm{C}, 5$ days & $0.3^{b}$ & $25.4^{\mathrm{a}}$ & $94^{\mathrm{ab}}$ \\
\hline $4 \mathrm{kPa} 10^{\circ} \mathrm{C}, 5$ days & $0.5^{\mathrm{a}}$ & $22.5^{\mathrm{a}}$ & $98^{\mathrm{b}}$ \\
\hline \multicolumn{4}{|c|}{$\frac{\text { Additional storage } 3 \text { days at } 101 \mathrm{kPa}}{20^{\circ} \mathrm{C}}$} \\
\hline$\overline{101 \mathrm{kPa}} 20^{\circ} \mathrm{C}, 5$ days & $0.9^{\mathrm{a}}$ & $18.5^{\mathrm{a}}$ & $69^{\mathrm{a}}$ \\
\hline $101 \mathrm{kPa} 10^{\circ} \mathrm{C}, 5$ days & $1.0^{\mathrm{a}}$ & $25.8^{\mathrm{b}}$ & $94^{\mathrm{b}}$ \\
\hline $4 \mathrm{kPa} 10^{\circ} \mathrm{C}, 5$ days & $0.9^{\mathrm{a}}$ & $26.4^{b}$ & $94^{\mathrm{b}}$ \\
\hline \multicolumn{4}{|l|}{ Upon removal } \\
\hline $101 \mathrm{kPa} 20^{\circ} \mathrm{C}, 11$ days & $1.1^{\mathrm{a}}$ & $20.1^{\mathrm{a}}$ & $83^{\mathrm{a}}$ \\
\hline $101 \mathrm{kPa} 10^{\circ} \mathrm{C}, 11$ days & $1.0^{\mathrm{b}}$ & $23.0^{\mathrm{b}}$ & $94^{\mathrm{ab}}$ \\
\hline $4 \mathrm{kPa} 10^{\circ} \mathrm{C}, 11$ days & $0.7^{\mathrm{b}}$ & $22.0^{\mathrm{ab}}$ & $100^{\mathrm{b}}$ \\
\hline \multicolumn{4}{|c|}{$\begin{array}{l}\text { Additional storage } 3 \text { days at } 101 \mathrm{kPa} \\
\underline{20^{\circ} \mathrm{C}}\end{array}$} \\
\hline $101 \mathrm{kPa} 20^{\circ} \mathrm{C}, 11$ days & $3.0^{\mathrm{a}}$ & $17.5^{\mathrm{a}}$ & $66^{\mathrm{a}}$ \\
\hline $101 \mathrm{kPa} 10^{\circ} \mathrm{C}, 11$ days & $1.7^{\mathrm{b}}$ & $21.3^{b}$ & $83^{b}$ \\
\hline $4 \mathrm{kPa} 10^{\circ} \mathrm{C}, 11$ days & $1.4^{\mathrm{b}}$ & $21.5^{\mathrm{b}}$ & $91^{\mathrm{b}}$ \\
\hline
\end{tabular}

Values are the mean of 3 replicates with 16 fruits in each replicate and the different letters indicate significant differences between treatments for each storage time $(\mathrm{p}<0.05)$. 


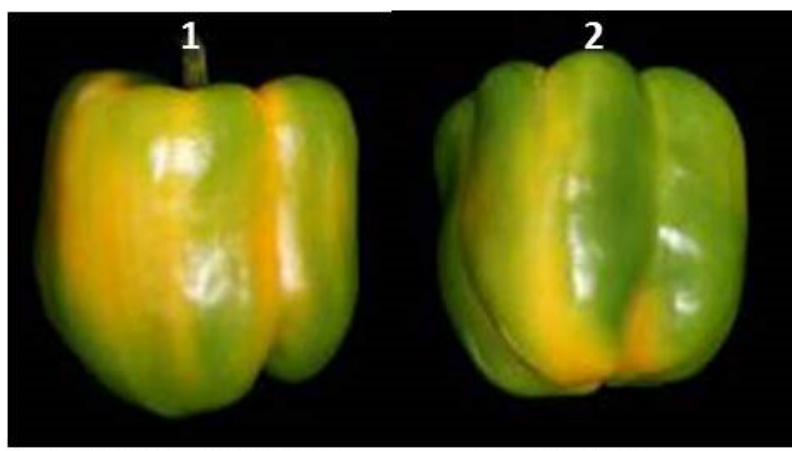

1 = severe degreening $2=50-75 \%$ green mainly yellow or

orange

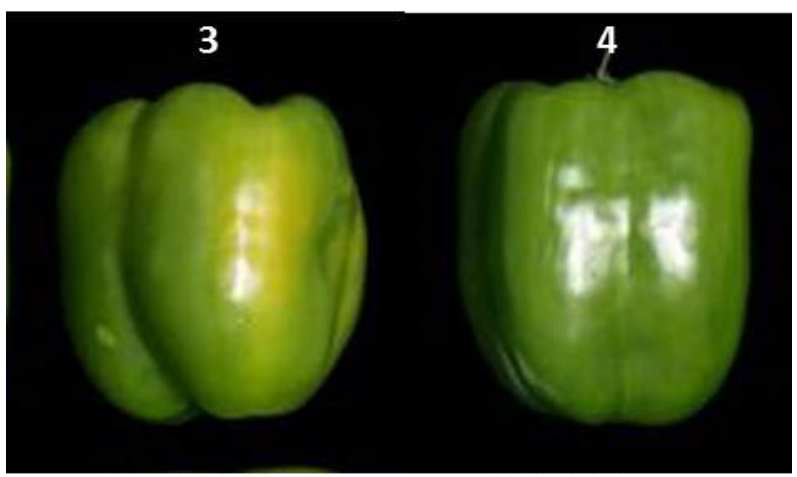

$3=\geq 75 \%$ green

$4=100 \%$ green

454

Figure 1. The green capsicums grading scale for skin degreening.

456

457

458

459

460

461

462

463

464

465

466 


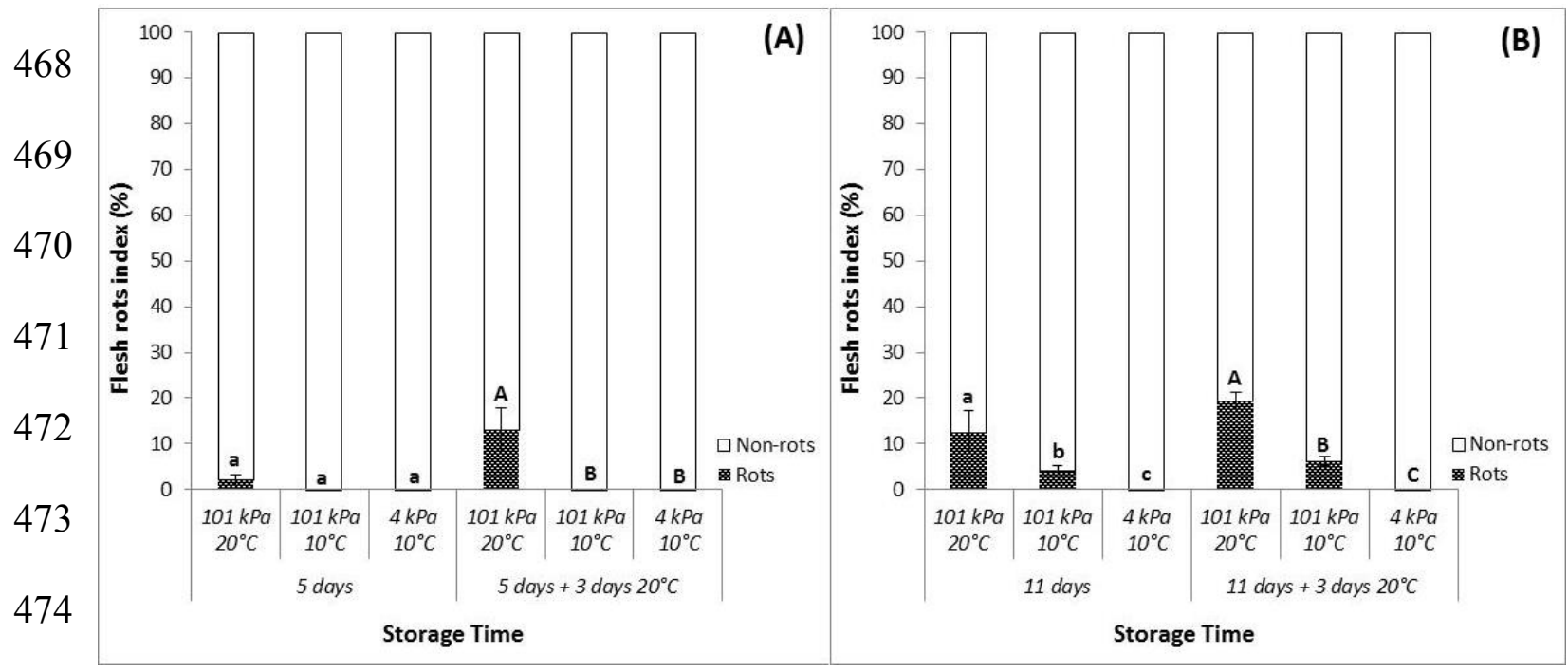

475

476 Figure 2. The capsicums flesh rots after stored for (A) 5 and (B) 11 days at different

477 pressure and temperature. The values are the mean of three replicates and the different

478 letters indicate significant differences between treatments for each storage time

$479 \quad(p<0.05)$.

480 


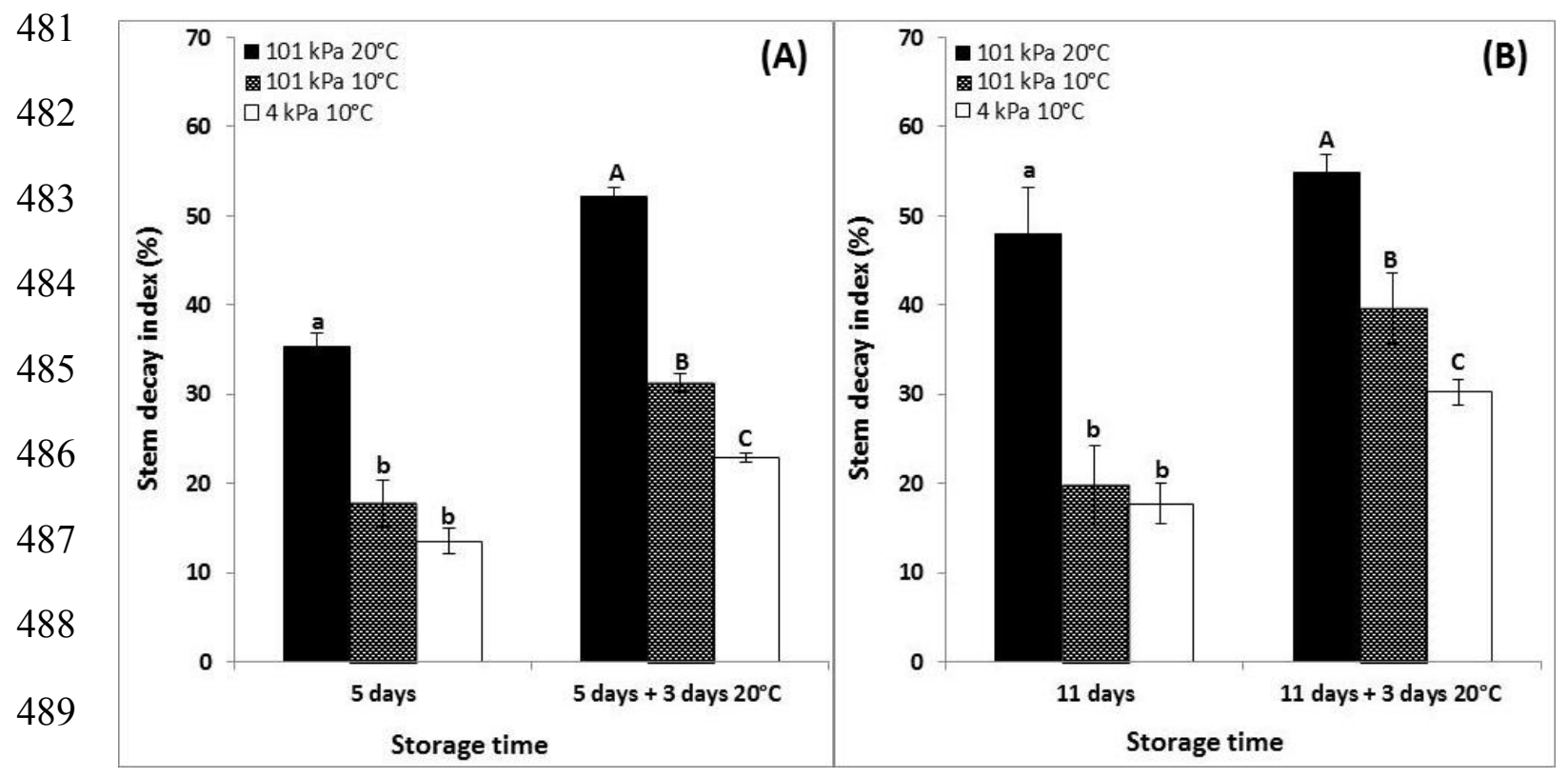

490

491 Figure3. The stem decay index of green capsicums after stored for (A) 5 and (B) 11

492 days at different pressure and temperature. The values are the mean of three replicates

493 and the different letters indicate significant differences between treatments for each

494 storage time $(p<0.05)$.

495 


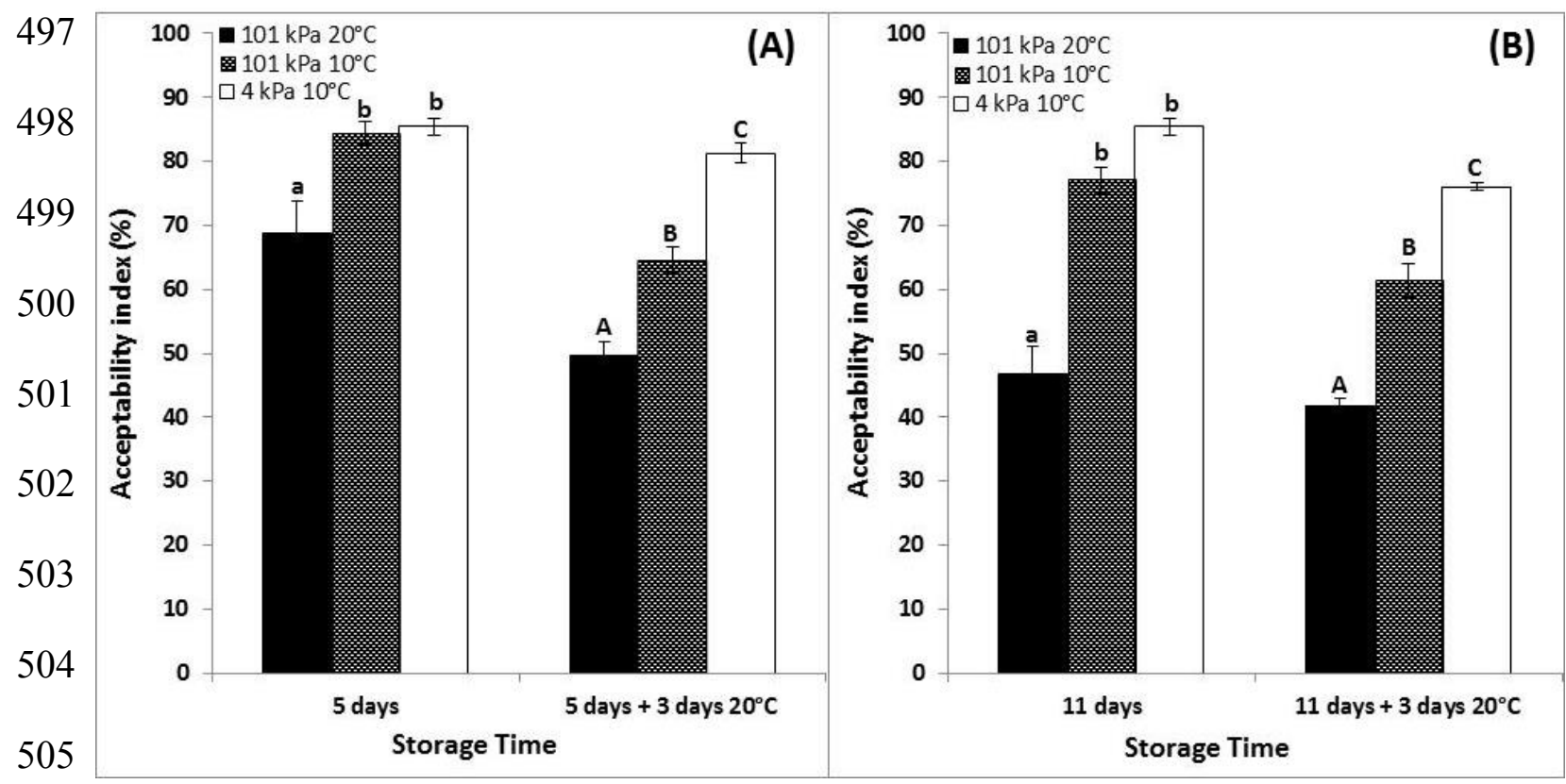

506

507 Figure 4. The overall acceptability index of green capsicums after stored for (A) 5 and

508 (B) 11 days at different pressure and temperature. The values are the mean of three

509 replicates and the different letters indicate significant differences between treatments for

510 each storage time $(p<0.05)$.

511

512

513

514

515

516

517

518 